\title{
CLASSIC AND MOLECULAR STUDY OF Giardia duodenalis IN CHILDREN FROM A DAYCARE CENTER IN THE REGION OF PRESIDENTE PRUDENTE, SÃO PAULO, BRAZIL
}

Nair Toshiko TASHIMA(1), Maria Jacira Silva SIMÕES(2), Clarice Queico Fujimura LEITE(2), Antonio FLUMINHAN(3), Marco Antonio NOGUEIRA(4) \& Ana Carolina MALASPINA(2)

\begin{abstract}
SUMMARY
Epidemiological studies on giardiasis by using molecular techniques such as RAPD (Randomly Amplified Polymorphic DNA) may give information on factors related to the transmission of Giardia duodenalis. The aim of this work was to assess the epidemiology of G. duodenalis in 101 children attended at a daycare center in Presidente Bernardes, SP, Brazil. After parasitological examinations in feces samples, 15 children presented cysts of G. duodenalis. Their respective parents, brothers and pets, besides the daycare center workers, also had their feces submitted to parasitological analysis. Seven mothers and nine brothers also presented G. duodenalis cysts, while fathers, daycare workers and pets (dogs) did not presented the parasite. Besides the 15 cases with G. duodenalis, other 23 children presented other enteroparasites (Entamoeba coli, Endolimax nana, Enterobius vermicularis, Ascaris lumbricoides and Trichuris trichiura). Samples of $G$. duodenalis cysts from children and their relatives were submitted to molecular typing by RAPD after genomic DNA extraction and amplification of a fragment of the $18 \mathrm{~S}$ rDNA region by PCR. After examining 31 isolates of $G$. duodenalis (children and their respective mothers and brothers), it was concluded that the parasite transmission occurred in children, probably during daily cohabitation at the daycare center, but not at home among their relatives or pets.
\end{abstract}

KEYWORDS: Giardia duodenalis; Enteroparasitosis; Daycare center; Children; RAPD; Epidemiology.

\section{INTRODUCTION}

Helminthiasis and protozoosis are intestinal infections of high incidence, generally affecting the human health and causing great public health concern ${ }^{24}$. Giardia duodenalis is the most frequent intestinal protozoa nowadays, either in technologically advanced societies or in developing countries ${ }^{4}$.

Giardia is a flagellated protozoa that was formerly mentioned by Antonie van Leewenhoek in 1681, when he found "animalcules" in his own feces. Two centuries later, in 1859, Lambl described it in detail and named Cercomonas intestinalis ${ }^{20}$. The cysts may be round or elliptic, measuring from 12 to $15 \mu \mathrm{m}$ in length and 6 to $8 \mu \mathrm{m}$ wide $^{27}$. They contain four nuclei, axonemes and median body. The trophozoite forms are 10 to $20 \mu \mathrm{m}$ in length by 5 to $15 \mu \mathrm{m}$ wide, and is drop-shaped as observed dorsal or ventrally. There is a concave adhesive disc in the ventral portion, four pairs of flagella, two axonemes and a median body. In this life stage they have two identical nuclei that are transcriptionally active.

Giardia infections are more common in children, with prevalence levels around $20 \%$ in some Brazilian regions ${ }^{17}$. This is one of the most frequent parasitosis in developing countries ${ }^{18}$, with great occurrence in daycare centers and orphanage due to its direct transmission way. In addition, along with Cryptosporidium, Giardia is the main intestinal protozoa transmitted by water worldwide, as a result of inappropriate water treatment or cross-contamination of potable water with sludge ${ }^{22}$.

The taxonomy of Giardia at species level has been quite confuse because it was mostly based on its origin and host instead of morphological features, amounting to more than 40 species. On the other hand, isolates morphologically identical have revealed to be genotypically distinct when based on molecular analysis ${ }^{22}$. Molecular analysis has revealed that the A genotype may be divided in two distinct subgroups. The A-I subgroup includes isolates from human origin and domestic animals, constituting the most potentially zoonotic group. The A-II subgroup includes only isolates from human origin. The B genotype consists of predominantly human origin, although some genotypes of animal origin have also been included in the group B-III. Other Giardia genotypes (C to G) morphologically similar to $G$. duodenalis have been identified in animals, amounting seven distinct genotypes ${ }^{16}$.

Molecular techniques, such as Random Amplified Polymorphic DNA (RAPD), have greater discernment power than morphological methods and have been used for genetic diversity studies ${ }^{31}$. Such technique is derived from Polymerase Chain Reaction (PCR) method, and consists

(1) Departamento de Parasitologia. Universidade do Oeste Paulista, Presidente Prudente, SP, Brasil

(2) Departamento de Ciências Biológicas. Faculdade de Ciências Farmacêuticas, Universidade Estadual Paulista, Campus de Araraquara, SP, Brasil.

(3) Universidade do Oeste Paulista, Presidente Prudente, SP, Brasil.

(4) Departamento de Microbiologia. Universidade Estadual de Londrina, Londrina, PR, Brasil.

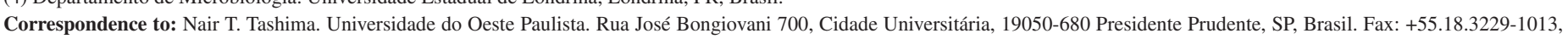

Phone: +55.18.3229-1084. E-mail: nairtashima@unoeste.br 


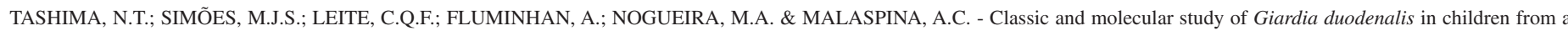
daycare center in the region of Presidente Prudente, São Paulo, Brazil. Rev. Inst. Med. trop. S. Paulo, 51(1): 19-24, 2009.

of amplifications of several anonymous loci in the genome by using a single primer with nucleotides of arbitrary sequence se,31. $^{30}$.

RAPD seems to be a promissory and efficient tool due to its fastness and precision in detecting genotypic differences among different $G$. duodenalis genotypes. In this case, its use for diagnostic purposes may be employed even before the clinical symptoms became visible ${ }^{21}$.

The aim of this work was to assess the prevalence of Giardia duodenalis in children attended at the daycare center of the Associação Municipal de Proteção ao Menor - Presidente Bernardes / SP and assess the relationships between $G$. duodenalis strains found in children with strains isolated from their parents, brothers, pets and daycare center's workers by means of PCR-RAPD.

\section{METHODS}

Study site and sampling: This research was carried out in children attended at the Associação Municipal de Proteção ao Menor, Presidente Bernardes county, located at the western region of São Paulo State $\left(22^{\circ} 00\right.$ '21" S $\left.51^{\circ} 33^{\prime} 10^{\prime \prime} \mathrm{W}\right)$, with territorial area about $754 \mathrm{~km}^{2}$ and population estimated in 15.5 thousand people, $70 \%$ of which living in the urban area (Fig. 1).

The selection criteria for children were age ranging from 0 to 6 years old and agreement from parents or legally responsible person in taking part in the research. In case of agreement, the following questionnaire was applied:

\begin{tabular}{|c|c|}
\hline \multicolumn{2}{|l|}{ Name: } \\
\hline Sex & (1) male (2) female \\
\hline $\begin{array}{l}\text { Medical } \\
\text { assistance }\end{array}$ & $\begin{array}{l}\text { (0) no one (1) SUS (2) Funrural (3) Athia } \\
\text { (4) Unoeste Saúde (5) Other }\end{array}$ \\
\hline Familiar income & $\begin{array}{l}\text { (0) no one (1) up to } 1 \text { minimum salary - MS } \\
\text { (2) } 1 \text { to } 2 \text { MS (3) } 2 \text { to } 3 \text { MS (4) more than } 3 \text { MS } \\
\text { (5) did not answer }\end{array}$ \\
\hline Sanitary at house & (0) no (1) yes \\
\hline Kind of house & (1) bricks (2) wood (3) other \\
\hline Water supply & (1) public pipeline (2) well (3) spring (4) river \\
\hline $\begin{array}{l}\text { Water for } \\
\text { drinking }\end{array}$ & $\begin{array}{l}\text { (1) filtered (2) boiled (3) stored in ceramic vials } \\
\text { (4) faucet }\end{array}$ \\
\hline $\begin{array}{l}\text { Sewage } \\
\text { destination }\end{array}$ & $\begin{array}{l}\text { (1) public net (2) dry tank (3) septic tank } \\
\text { (4) soil surface (5) water stream }\end{array}$ \\
\hline $\begin{array}{l}\text { Garbage } \\
\text { destination }\end{array}$ & $\begin{array}{l}\text { (1) soil surface (2) digging (3) burning } \\
\text { (4) water stream (5) throw away from home } \\
\text { (6) public collection }\end{array}$ \\
\hline Pets at home & (0) no (1) yes If yes, (1) dog (2) cat (3) other \\
\hline Use of shoes & \multirow{4}{*}{ (0) no (1) yes (2) sometimes } \\
\hline Diarrhea & \\
\hline Vomit & \\
\hline Stomachache & \\
\hline $\begin{array}{l}\text { During the } \\
\text { interview }\end{array}$ & $\begin{array}{l}\text { (1) diarrhea (2) vomit (3) stomachache } \\
\text { (4) } 1+2(5) 1+3 \text { (6) } 2+3 \text { (7) } 1+2+3\end{array}$ \\
\hline $\begin{array}{l}\text { Parasitological } \\
\text { results }\end{array}$ & \\
\hline
\end{tabular}

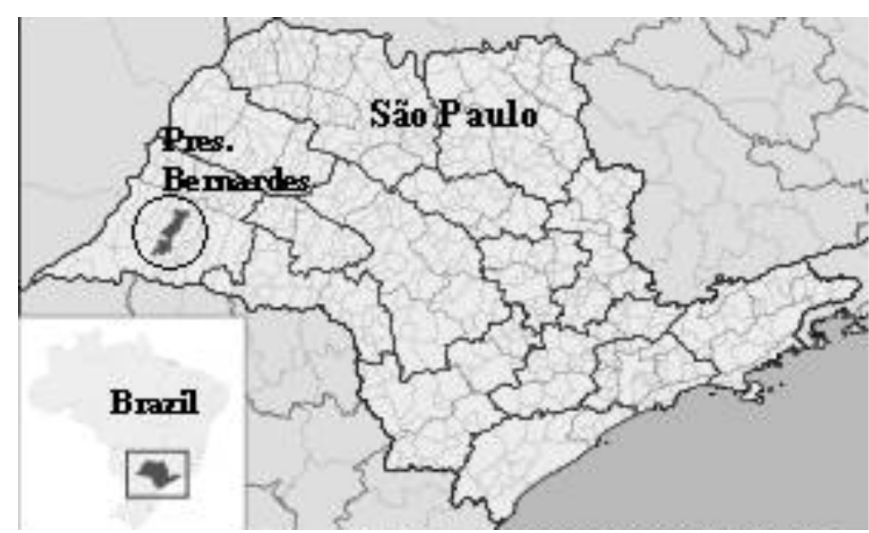

Fig. 1 - Location of the study area.

In order to find a possible relationship between $G$. duodenalis isolated from children, feces samples from their parents, brothers, and/or pets were also taken when the parasitological results for $G$. duodenalis was positive in the respective child. Feces samples were also taken from nine workers at the daycare center. Three samples were taken in a period of ten days in order to increase the probability of obtaining cysts of $G$. duodenalis, which have an intermittent elimination ${ }^{26}$. The samplings occurred from January to July, 2004.

The Human Subject Ethics Committee at Unoeste previously approved the research (Process No. 054).

Parasitological assessment: Feces samples were examined at the Laboratory for Clinical Analyses, Pharmacy College, Unoeste - Campus I, Presidente Prudente, SP. Three methods were employed in order to recover enteroparasites: Lutz ${ }^{6}$ method for eggs, Faust et al. ${ }^{1}$ method to concentrate the protozoa cysts and helminths eggs, and Rugai et al. ${ }^{29}$ method for recovery of larval forms of helminths.

Purification of G. duodenalis cysts from human feces: This procedure was performed according to ROBERTS-THOMPSON et al. ${ }^{19}$ with minor adaptations. Feces samples were diluted in water (1:5), passed through surgical cotton gauze and centrifuged at $700 \times g$ for five min. The supernatant was discharged, the sediment suspended in water and the process repeated four more times as before in order to remove debris. The resulting sediment was suspended in $3 \mathrm{~mL}$ water, added $3 \mathrm{~mL}$ of $1 \mathrm{M}$ sucrose and centrifuged at $180 \mathrm{x} g$ for $20 \mathrm{~min}$. The cysts in suspension were transferred to another centrifuge tube, suspended in water and centrifuged again at $700 \mathrm{x} g$ for $10 \mathrm{~min}$. The resulting sediment was suspended in 3 $\mathrm{mL}$ of water, added $3 \mathrm{~mL}$ of sucrose $0.75 \mathrm{M}$ and centrifuged at $250 \mathrm{xg}$ for $10 \mathrm{~min}$. The cysts in suspension were washed in water to remove the sucrose residues and finally suspended in $1 \mathrm{~mL}$ of water.

DNA extraction: DNA extraction and RAPD analysis were carried out at the Laboratory for Cytogenetic and Molecular Biology, Unoeste - Campus II.

The purified cysts, $c a$. 50 per sample, were centrifuged at $700 \mathrm{x} g$ for five min., the supernatant discarded, and the pellet received $500 \mu \mathrm{L}$ of TEN solution $(100 \mu \mathrm{L}$ of $1 \mathrm{M}$ Tris- $\mathrm{HCl} ; 200 \mu \mathrm{L}$ of $0.5 \mathrm{M}$ EDTA, $200 \mu \mathrm{L}$ of $5 \mathrm{M} \mathrm{NaCl} ; \mathrm{pH} 8.0$ ). The suspension was then transferred to liquid nitrogen for five min, followed by water-bath at $97{ }^{\circ} \mathrm{C}$ for five min. This 


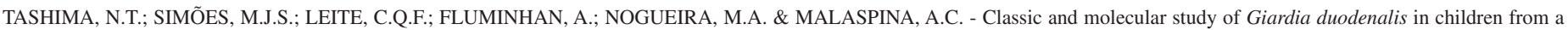
daycare center in the region of Presidente Prudente, São Paulo, Brazil. Rev. Inst. Med. trop. S. Paulo, 51(1): 19-24, 2009.

procedure was carried out three times. The suspension, after cooled in ice, received $5 \mu \mathrm{L}$ of lysozime, mixed and incubated in water-bath at 37 ${ }^{\circ} \mathrm{C}$ for one $\mathrm{h}$. After that, $50 \mu \mathrm{L}$ of $5 \%$ sodium dodecyl sulfate was added, mixed, followed by addition of $2.5 \mu \mathrm{L}$ of $\mathrm{K}$ proteinase $(20 \mathrm{mg} / \mathrm{mL}$ of $\mathrm{H}_{2} \mathrm{O}$ ) and again incubated in water-bath for $30 \mathrm{~min}$. The suspension was centrifuged at $7500 \times \mathrm{g}$ for five min and the supernatant discarded. The pellet was resuspended in isopropylic alcohol and again centrifuged at $15000 \mathrm{x} g$ for five min. The resulting pellet was washed in $70 \%$ alcohol and resuspended in $200 \mu \mathrm{L}$ of TE solution (10 mM Tris; $1 \mathrm{mM}$ EDTA) and the DNA concentration determined spectrophotometrically.

PCR with specific primers for G. duodenalis: A fragment with 292 bp of the 18S rDNA region flanked by primers RH11 (5'-CAT CCG GTC GAT CCT GCC-3') and RH4 (5'-AGT CGA ACC CTG ATT CTC CGC CAG G-3') ${ }^{11}$ (Invitrogen ${ }^{\mathrm{TM}}$ ) was amplified by PCR. The reaction mix $(25 \mu \mathrm{L})$ was composed by $2.5 \mu \mathrm{L}$ of $10 \mathrm{x}$ PCR buffer $\mathrm{pH} 8.5,0.75 \mu \mathrm{L}$ of $50 \mathrm{mM} \mathrm{MgCl}{ }_{2}, 0.5 \mu \mathrm{L}$ of $200 \mu \mathrm{M}$ dNTPs, $0.5 \mu \mathrm{L}$ of each primer $(0.1$ $\mathrm{nM}), 1.25 \mu \mathrm{L}$ of dimethyl sulfoxide (DMSO), $0.2 \mu \mathrm{L}$ (0.1 U) of Taq DNA polymerase, $17.8 \mu \mathrm{L}$ of ultrapure water, and $1 \mu \mathrm{L}(40 \rho \mathrm{g})$ of template DNA. The amplification reaction was: forty-three cycles at $94{ }^{\circ} \mathrm{C}$ for 60 s, $53{ }^{\circ} \mathrm{C}$ for $40 \mathrm{~s}$, and extension at $72{ }^{\circ} \mathrm{C}$ for two min. The amplification product was verified under transluminator in $1.5 \%$ agarose gel after electrophoresis and treatment with ethyl bromide.

PCR with arbitrary primers (RAPD): The RAPD (Random Amplified Polymorphic DNA) technique ${ }^{23}$ was carried out in $25 \mu \mathrm{L}$ of reaction mix containing $0.1 \mathrm{U}$ of Taq DNA polymerase (Promega $\left.{ }^{\mathrm{TM}}\right), 0.2 \mathrm{mM}$ of dNTPs, $1.5 \mathrm{mM}$ of $\mathrm{MgCl}_{2}, 50 \mathrm{mM}$ of $\mathrm{KCl}, 10 \mathrm{mM}$ of Tris- $\mathrm{HCl}(\mathrm{pH} 8.5), 1 \mathrm{ng}$ of DNA template, and $1 \mu \mathrm{M}$ of each primer: IMIA2 (5' TGC CGA GCT G 3'), IMIA3 (5' AGT CAC GCA C 3'), IMIA5 (5' AGG GGT CTT G 3'), IMIA8 (5' GTG ACG TAG G 3'), and IMIA10 (5' GTG ATC GCA G 3'). The primers were selected randomly among the available at the Laboratory for Molecular Genetics. Forty-three cycles consisting of denaturation at $94{ }^{\circ} \mathrm{C}$ for $60 \mathrm{~s}$, annealing at $50{ }^{\circ} \mathrm{C}$ for one min and extension at $72{ }^{\circ} \mathrm{C}$ for five min, were performed for each random primer.

Agarose gel electrophoresis for visualization of amplified DNA: PCR products were loaded on $1.5 \%$ agarose gel in the presence of bromopenol blue in the loading buffer (TBE 1X) and submitted to electrophoresis $(100 \mathrm{~V}, 30 \mathrm{~min})$ at room temperature. The molecular masses of the bands were estimated by comparison with molecular mass standards (100 bp, Promega $\left.{ }^{\mathrm{TM}}\right)$. After electrophoresis, the gel was photodocumented on a transluminator and analyzed with the image analyzer Alpha-innotech.

$\boldsymbol{R A P D}$ products analysis: The RAPD products were analyzed at Department for Biological Sciences, College of Pharmaceutical Sciences, Araraquara (Universidade Estadual Paulista) with the software Gel Compar II (Applied Maths). A consensus dendrogram was generated based on Dices's coefficient of similarity and UPGM (Unweighed Pair Group Method with Arithmetic Mean) for grouping. The intensity of bands was not considered in the analysis.

\section{RESULTS}

Parasitological assessments: According to the selection criteria, 101 out of 131 children attended at the daycare center had their feces sampled. From these, 61 were between 0 and 3 years old and 40 were between 4 and
6 , and $61 \%$ were girls. The most part of the families (80\%) had familiar inputs between two and three salaries and all children lived in houses supplied with water from municipal pipes. Most of the children (83\%) were asymptomatic, while diarrhea was the most common complaining in 16 cases. Most of the fecal samples were loose, with few exceptions that were diarrheic.

Sixty-two children had no enteroparasite, 15 presented G. duodenalis, 23 presented other parasite than $G$. duodenalis, while only one presented simultaneous occurrence of $G$. duodenalis and other enteroparasite ( $E$. vermicularis). Entamoeba coli occurred in nine cases, while Endolimax nana occurred in three cases. Helminths, such as Enterobius vermicularis occurred in nine cases, one with eggs of Ascaris lumbricoides, and other with eggs of Trichuris trichiura. In children with diarrhea, four presented G. lamblia (one of them in association with E. vermicularis), one presented E. vermicularis, two presented E. coli, and nine had no enteroparasites.

When $G$. duodenalis was confirmed in a child, his/her family members (parents and brothers) and pets (five cases of children presenting G. duodenalis which had dogs at home) were also submitted to feces examination. In 35 fecal samples from family members, 16 contained $G$. duodenalis, comprising seven mothers and nine brothers. Fathers, pets or the nine daycare workers did not have G. duodenalis in their fecal samples. Thus, a total of 31 G. duodenalis isolates were considered in this study.

Genetic variability of G. duodenalis by RAPD: The banding profiles generated by each primer were able to detect genetic variability among the $G$. duodenalis isolates. As illustration, only profiles generated with the primers IMIA8 are shown (Fig. 2a and 2b). Each primer produced from two to eight fragments, depending on the $G$. duodenalis isolate and the primer used in the reaction.

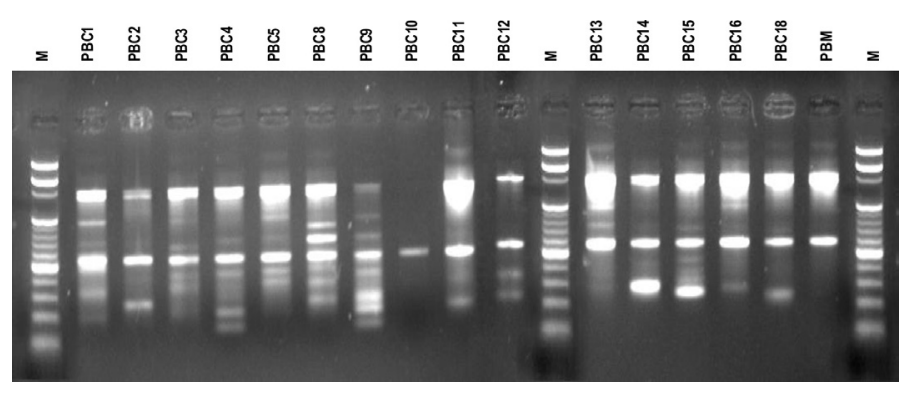

Fig. 2a - Agarose gel stained with ethidium bromide, showing the RAPD profiles of Giardia duodenalis isolates, obtained with the primer IMIA8. PBC = Isolated from child; PBM = Isolated from mother; $\mathrm{M}=$ Molecular weight marker.

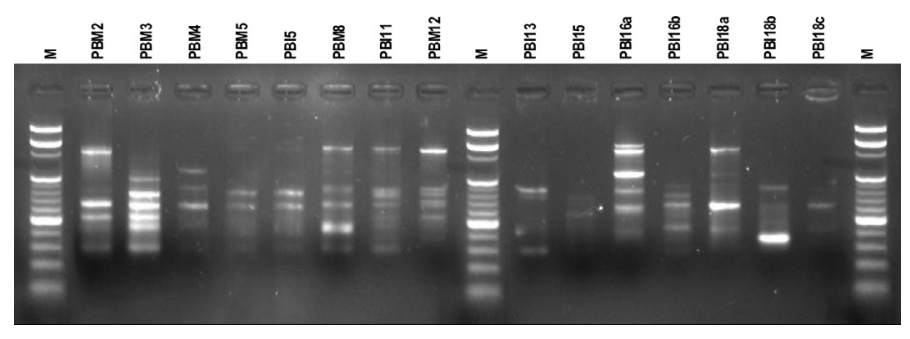

Fig. 2b - Agarose gel stained with ethidium bromide, showing the RAPD profiles of Giardia duodenalis isolates, obtained with the primer IMIA8. PBM = Isolated from mother; PBI = Isolated from brother; $\mathrm{M}=$ Molecular weight marker. 
TASHIMA, N.T.; SIMÕES, M.J.S.; LEITE, C.Q.F.; FLUMINHAN, A.; NOGUEIRA, M.A. \& MALASPINA, A.C. - Classic and molecular study of Giardia duodenalis in children from a daycare center in the region of Presidente Prudente, São Paulo, Brazil. Rev. Inst. Med. trop. S. Paulo, 51(1): 19-24, 2009.

Greater polymorphism was obtained with the primer IMIA 8, indicating different banding pattern among all isolates. Except IMIA 5, all primers produced strong amplicons. For this reason, the weak amplicons obtained with IMIA 5 were not considered in the similarity analysis. The other four primers produced different genetic profiles that were analyzed simultaneously to establish the relationships between the isolates by means of a dendrogram of similarity (Fig. 3).
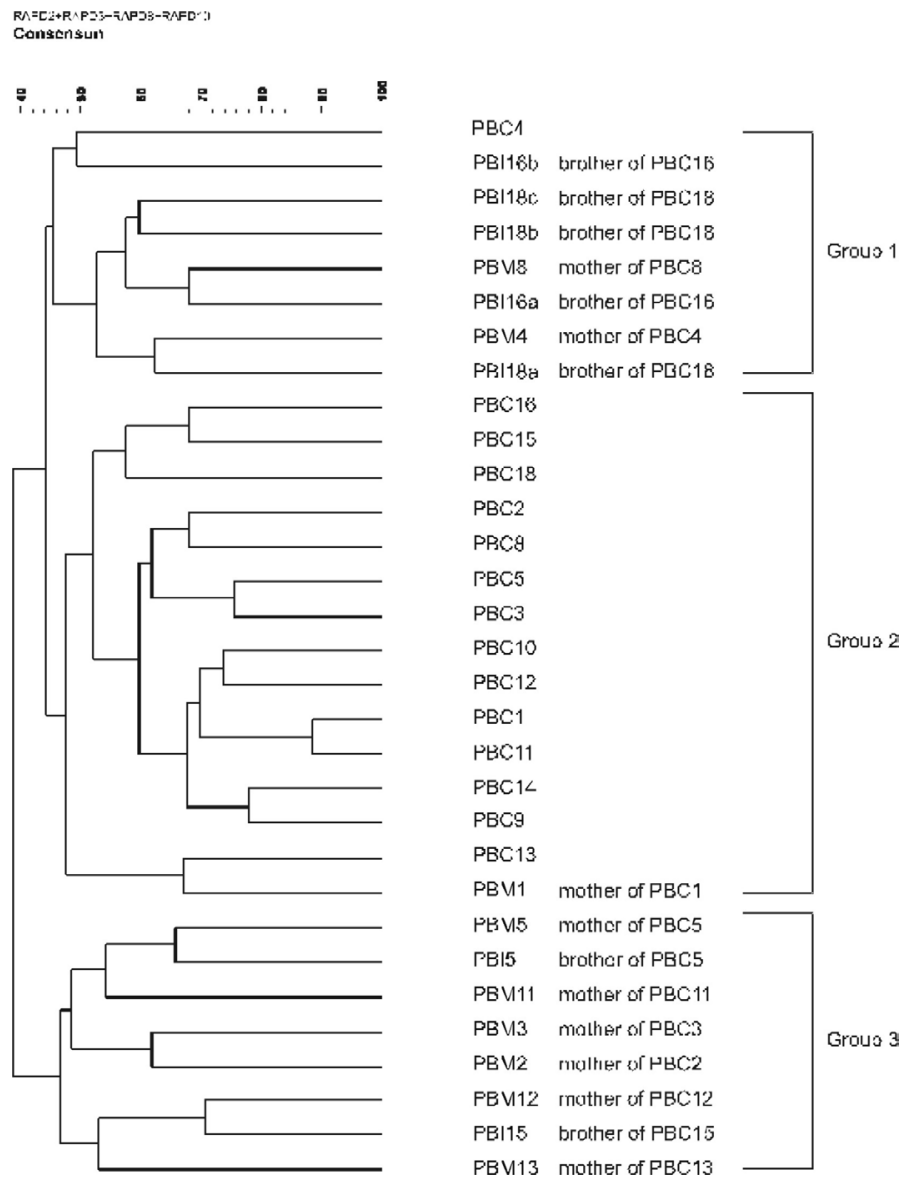

Fig. 3 - Consensun dendrogram based on RAPD profile of $18 \mathrm{~S}$ rDNA fragments obtained from 31 isolates of $G$. duodenalis and amplified with the random primers IMIA2, IMIA3, IMIA8, and IMIA10. PBC $=$ Isolated from child; PBM $=$ Isolated from mother; PBI $=$ Isolated from brother.

The grouping analysis resulted in three genetic groups with similarity about $45 \%$ one another. The first group was formed by eight isolates, seven of them obtained from relatives and only one obtained from a child attended at the daycare center, including his mother. The second group was formed by 15 isolates, 14 of them were children attended at the daycare center and only one was isolated from the mother of one of the child. The third group was formed by eight isolates obtained from relatives (mother or brothers) of the children attended at the daycare center. Among the children in the group 2, the greatest similarity was found between the isolates obtained from the children PBC1 and PBC11, with $88 \%$ of similarity.

\section{DISCUSSION}

Human enteroparasitoses are a public health concern and can be considered as indicators of social-economic conditions of a population. Due to the lower mobility and greater vulnerability, children under five years old can indicate the contamination level of a given region ${ }^{25}$.

Recent reductions in prevalence of intestinal parasitic infections in some Brazilian regions have been related to improvement of familiar incomings, maternal scholarship, housing, sanitary conditions and health services $^{7}$. In this work, $38.6 \%$ of the children under six years old attended at the daycare center in Presidente Bernardes-SP showed cysts or eggs of at least one parasite. This result is quite above the encountered in children up to six years old attended at a daycare center in Belo Horizonte, Minas Gerais State, Brazil $(24.6 \%)^{14}$. The protozoan G. duodenalis and the helminth E. vermicularis were the most frequent in our work, with 16 and $9 \%$ of prevalence, respectively. Assessment carried out with children attending the primary school in Kenya revealed prevalence of $87 \%$ for ancylostomosis, $88 \%$ for trichuriosis and $31 \%$ for ascariasis ${ }^{5}$. In Holambra, São Paulo State, Brazil, the most frequent helminth was Ascaris lumbricoides ${ }^{9}$, while in this work E. vermicularis was the most frequent. E. vermicularis expels embryonic eggs that may be transmitted directly by fecal-oral ways, what can explain its high prevalence among children in this study. Similar levels of giardiasis prevalence among children have been reported ${ }^{17}$, but in that case the assessments were made in children that were attended in a hospital in Goiânia, Goiás State, Brazil, due to diarrhea.

Despite the higher proportion of girls among the children (61\%), only five presented giardiasis, while 10 boys presented this intestinal parasite. Previous work has also showed higher prevalence of intestinal parasitic infections in males than females, without an apparent reason ${ }^{4}$.

Although giardiasis is related to age and social-economical level ${ }^{11}$, other risk factors for infection have been identified, such as presence of pets at home, specially cats, number of children at home, food hygiene, daycare centers attendance, and living on rural areas ${ }^{17}$. The occurrence of children presenting G. duodenalis that had pets at home was low, and in no one case pets were suspect to be the source of contamination, given that they did not present $G$. duodenalis cysts. Nevertheless, the zoonotic transmission between dogs and children may also occur ${ }^{6}$.

Besides the several risk factors presented before, giardiasis can be transmitted by fecal-oral ways among children that are attended in daycare centers ${ }^{5}$ or even among the family members at home. Facing the high frequency of giardiasis among the children in this study, it was hypothesized that the transmission way could occur among children during their daily contact at daycare center or by household contact at home. All children in this study lived in houses supplied with water from municipal pipelines, what reduce the chances that infection with $G$. duodenalis had correlation with drinking water ${ }^{28}$, supposing adequate water treatment before distribution.

The occurrence of Giardia duodenalis in children was confirmed by PCR using specific primers for this species. Different $G$. duodenalis isolates studied by different authors, in spite of morphological appearance, have showed different degrees of genetic diversity ${ }^{2,3,8,12}$. Two hypotheses could be considered to explain such heterogeneity ${ }^{2}$. Firstly, the 
TASHIMA, N.T.; SIMÕES, M.J.S.; LEITE, C.Q.F.; FLUMINHAN, A.; NOGUEIRA, M.A. \& MALASPINA, A.C. - Classic and molecular study of Giardia duodenalis in children from a daycare center in the region of Presidente Prudente, São Paulo, Brazil. Rev. Inst. Med. trop. S. Paulo, 51(1): 19-24, 2009.

different $G$. duodenalis isolates form only one species with high degree of intraspecific variation. Second, G. duodenalis would be a complex formed by two or more species morphologically similar.

Both genetic heterogeneity and zoonotic potential of $G$. duodenalis may differ according to geographic region ${ }^{13}$ and thus it is essential to typify the parasite in different regions. The heterogeneity of $G$. duodenalis isolated from human and dogs was not the same in two Australian communities $^{8}$. In an urban area, isolates from human and dogs had the same genotype, probably because the man was contaminated with the parasites from dogs or vice-versa. However, in an aborigine community, isolates from dogs and humans belonged to different genotypes.

RAPD has been widely used to study the genetic diversity among G. duodenalis isolates. This technique employs random primers and detects polymorphisms in different loci, allowing for a wider view of the genome, independently on the knowledge about the degree of ploidia of the microorganism to be studied. Previous work with RAPD showed genetic variability among $G$. duodenalis isolates ${ }^{15}$. Fourteen $G$. duodenalis isolates extracted from different animals and geographical region were characterized by RAPD and compared with previous data based on isoenzyme analysis of the same isolates. Although the authors had found close correlation between the two methods, some inconsistencies were observed. Seven out of fourteen isolates grouped differently when considering each technique, although the 14 isolates had been separated in 10 groups in both cases.

The characterization of $G$. duodenalis isolates in this work by RAPD also revealed genetic variability among the isolates. In 31 isolates, 31 different genetic profiles were found, considering the set of random primers used in the reaction. The highest similarity among the isolates $(88 \%)$ occurred between two isolates from children attended at the daycare center. Most of isolates from children showed genetic profile forming only one genetic group (group 2), with about $45 \%$ of similarity, except one isolate. The isolates from relatives (mothers and brothers) were divided between two other genetic groups with about $45 \%$ of similarity (Groups 1 and 3), in which only one isolate from children was included in the group 1 . These observations allowed us to conclude that children are not bringing the parasite from their houses. In addition, no one worker at the daycare center presented giardiasis. These results exclude the drinkable water and food at the daycare center as possible way of dissemination, as the nine workers drink the same water and eat the same food. Thus, it is possible that the transmission among children occurred during their contact at the daycare center.

Just after obtaining results of feces examination, the director of daycare center and children parents were informed, and children with positive cases of parasitosis received free medical assistance. In addition, parents and daycare center employees listened an explanation about enteroparasitosis transmission and how to act to reduce or avoid infections.

Despite recent advances, these results show the need for improvement of sanitary conditions and synchronized programs of assistance aiming the sanitary education, continuous assessment of enteroparasitic infections and participation and checking the effectiveness of recommended treatments. The combination of such actions would enable for an improvement of children life conditions and the whole community as well.
In summary, the prevalence of $G$. duodenalis $(16 \%)$ in children attended at the daycare center (Associação Municipal de Proteção ao Menor em Presidente Bernardes, SP) is on the average found in Brazil. By means of RAPD technique, all $G$. duodenalis isolates were genetically dissimilar, forming three main groups, with about $45 \%$ of similarity one another. The most part of the isolates obtained from children at the daycare center $(93 \%)$ grouped together, showing greater similarity among them. On the other hand, the isolates obtained from their relatives formed other groups. Such results allowed us to conclude that infections in children at the daycare center probably occurred person-person, as a result of their daily contact.

\section{RESUMO}

\section{Estudo clássico e molecular de Giardia duodenalis em crianças atendidas em uma creche na região de Presidente Prudente, São Paulo, Brasil}

Estudos epidemiológicos sobre giardíase por técnicas moleculares como a RAPD (Amplificação aleatória do DNA polimórfico) podem contribuir para o entendimento de fatores relacionados à transmissão de Giardia duodenalis. O objetivo desse trabalho foi estudar a epidemiologia de G. duodenalis em 101 crianças atendidas em uma creche em Presidente Bernardes, SP, Brasil. Após exames parasitológicos em amostras de fezes, 15 crianças apresentaram cistos de G. duodenalis. Seus respectivos pais, irmãos e animais domésticos, além dos funcionários da creche, foram submetidos a exames parasitológicos de fezes. Destes, sete mães e nove irmãos apresentaram G. duodenalis, enquanto os pais, funcionários da creche e animais de estimação (cães) não apresentaram o parasita. Além dos 15 casos com G. duodenalis, outras 23 crianças apresentaram outros enteroparasitas (Entamoeba coli, Endolimax nana, Enterobius vermicularis, Ascaris lumbricoides e Trichuris trichiura). As amostras contendo cistos de G. duodenalis das crianças e de seus parentes foram submetidas à análise molecular por RAPD após extração do DNA genômico e amplificação de um fragmento de uma região do rDNA $18 \mathrm{~S}$ por PCR. Entre os 31 isolados de G. duodenalis (crianças e suas respectivas mães e irmãos), concluiu-se que a transmissão dos parasitas ocorreu entre as crianças, provavelmente durante seu convívio na creche, mas não foi decorrente do convívio familiar ou animais de estimação.

\section{ACKNOWLEDGMENTS}

To Universidade do Oeste Paulista (UNOESTE) for financial support. M.A.N is CNPq scholar.

\section{REFERENCES}

1. AMATO NETO, V.; CAMPOS, R. \& FERREIRA, C.S. - Diagnóstico das parasitose intestinais pelo exame de fezes. São Paulo, Atheneu, 1963.

2. ANDREWS, R.H.; ADAMS, M.; BOREHAM, P.F.; MAYRHOFER, G. \& MELONI, B.P. - Giardia intestinalis: eletrocphoretic evidence for a species complex. Int. J. Parasit., 19: 183-190, 1989.

3. ANDREWS, R.H.; MONIS, P.T.; EY, P.L. \& MAYRHOFER, G. - Comparison of the levels of intra-specific genetic variation within Giardia muris and Giardia intestinalis. Int. J. Parasit., 28: 1179-1185, 1998.

4. ARANI, A.S.; ALAGHEHBANDAN, R.; AKHLAGHI, L.; SHAHI, M. \& LARI, A.R. - Prevalence of intestinal parasites in a population in south of Tehran, Iran. Rev. Inst. Med. trop. S. Paulo, 50: 145-149, 2008 
TASHIMA, N.T.; SIMÕES, M.J.S.; LEITE, C.Q.F.; FLUMINHAN, A.; NOGUEIRA, M.A. \& MALASPINA, A.C. - Classic and molecular study of Giardia duodenalis in children from a daycare center in the region of Presidente Prudente, São Paulo, Brazil. Rev. Inst. Med. trop. S. Paulo, 51(1): 19-24, 2009.

5. CARDOSO, G.S.; SANTANA, A.D.C. \& AGUIAR, C.P. - Prevalência e aspectos epidemiológicos da giardíase em creches no Município de Aracajú, SE, Brasil. Rev. Soc. bras. Med. trop., 28: 25-31, 1995

6. ELÍGIO-GARCÍA, L.; CORTES-CAMPOS, A. \& JIMÉNEZ-CARDOSO, E. Genotype of Giardia intestinalis isolates from children and dogs and its relationship to host origin. Parasit. Res., 97: 1-6, 2005.

7. FERREIRA, M.U.; FERREIRA, C.S. \& MONTEIRO, C.A. - Tendência secular das parasitoses intestinais na infância na cidade de São Paulo (1984-1996). Rev. Saúde públ. (S. Paulo), 34: 73-83, 2000.

8. HOPKINS, R.M.; MELONI, B.P.; GROTH, D.M. et al. - Ribossomal RNA sequencing reveals differences between the genotypes of Giardia isolates recovered from humans and dogs living in the some locality. J. Parasit., 83: 44-51, 1997.

9. KOBAYASHI, J.; HASEGAWA, H.; FORLI, A.A. et al. - Prevalence of intestinal parasitic infection in five farms in Holambra, São Paulo, Brazil. Rev. Inst. Med. trop. S. Paulo, 37: 13-18, 1995.

10. LUTZ, A.O. - Schistosoma mansoni, segundo observações feitas no Brasil. Mem. Inst. Oswaldo Cruz, 11: 121-155, 1919.

11. MACHADO, R.C.; MARCARI, E.L.; CRISTANTE, S.; CRISTANTE V. \& CARARETO, C.M.A. - Giardíase e helmintíase em crianças de creches e escolas de primeiro e segundo graus (públicas e privadas) da cidade de Mirassol (SP, Brasil). Rev. Soc. bras. Med. trop., 32: 697-704, 1999.

12. MAYRHOFER, G.; ANDREWS, R.H.; EY, P.L. \& CHILTON, N.B. - Division of Giardia isolates from humans into two genetically distinct assemblages by electrophoretic analysis of enzymes encoded at 27 loci and comparison with Giardia muris. Parasitology, 111: 11-17, 1995.

13. MELONI, B.P.; LYMBERY, A.J. \& THOMPSON, R.C.A. - Isoenzyme electrophoresis of 30 isolates of Giardia from humans and felines. Amer. J. trop. Med. Hyg., 38: $65-73,1988$.

14. MENEZES, A.L.; LIMA, V.M.P.; FREITAS, M.T.S. et al. - Prevalence of intestinal parasites in children from public daycare centers in the city of Belo Horizonte, Minas Gerais, Brazil. Rev. Inst. Med. trop. S. Paulo, 50: 57-59, 2008

15. MORGAN, U.M.; CONSTANTINE, C.C.; GRENE, W.K. \& THOMPSON, R.C.A. - RAPD (random amplified polymorphic DNA) analysis of Giardia DNA and correlation with isoenzyme data. Trans. roy. Soc. trop. Med. Hyg., 87: 702-705, 1993.

16. OLSON, M.E.; O’HANDLEY, R.M.; RALSTON, B.J. et al. - Update on Cryptosporidium and Giardia infections in cattle. Trends Parasit., 20: 185-190, 2004.

17. PEREIRA, M.G.C.; ATWILL, E.R. \& BARBOSA, A.P. - Prevalence and associated risk factors for Giardia lamblia infection among children hospitalized for diarrhea in Goiânia, Goiás State, Brazil. Rev. Inst. Med. trop. S. Paulo, 49: 139-145, 2007.

18. RIVERA, M.; LA PARTE, M.A.; HURTADO, P.; MAGALDI, L. \& COLLAZO, M. - Giardiasis intestinal. Mini-revision. Invest. Clín., 43: 119-128, 2002.
19. ROBERTS-THOMPSON, I.C.; STEVENS, D.P.; MAHMOUD, A.A. \& WARREN, K.S. - Acquired resistance to infection in an animal model of giardiasis. J. Immunol., 117: 2036- 2037, 1976

20. ROCHA, M.O. - Giardia duodenalis: axenização e caracterização de três isolados do Brasil, empregando parâmetros biológicos, bioquímicos, imunológicos e moleculares. Belo Horizonte, 2003. (Tese de Doutorado em Parasitologia Universidade Federal de Minas Gerais).

21. SEDINOVÁ, J.; FLEGR, J.; EY, P.L. \& KULDA, J. - Use of random amplified polymorphic DNA (RAPD) analysis for the identification of Giardia intestinalis subtypes and phylogenetic tree construction. J. Eukar. Microbiol., 50: 198-203, 2003.

22. SMITH, H.V.; CACCIÒ, S.M.; TAIT, A.; McLAUCHLIN, J. \& THOMPSON R.C.A. - Tools for investigating the environmental transmission of Cryptosporidium and Giardia infections in humans. Trends Parasit., 22: 160-167, 2006.

23. STEINDEL, M.; DIAS NETO, E.; MENEZES, C.L.P.; ROMANHA, A.J. \& SIMPSON, A.J.- Random amplified polymorphic DNA analysis of Trypanosoma cruzi strains. Molec. Biochem. Parasit., 60: 71-79, 1993.

24. STEPHENSON, L.S. - Los helmintos, importante factor de malnutrición. Foro Mundial Salud, 15: 184-187, 1994

25. TASHIMA, N.T. \& SIMÕES, M.J.S. - Enteroparasitic occurrence in fecal samples analyzed at the University of Western São Paulo-Unoeste Clinical Laboratory, Presidente Prudente, São Paulo State, Brazil. Rev. Inst. Med. trop. S. Paulo, 46: 243-248, 2004

26. THOMPSON, R.C.; REYNOLDS, J.A. \& MENDIS, A.H.W. - Giardia and giardiasis. Advanc. Parasit., 32: 71-160, 1993.

27. THOMPSON, R.C.A.; HOPKINS, R.M. \& HOMAN, W.L. - Nomenclature and genetic groupings of Giardia infecting mammals. Parasit. today, 16: 210-213, 2000 .

28. TSUYUOKA, R.; BAILEY, J.W.; NERY GUIMARÃES, A.M.; GURGEL, R.O \& CUERVAS, L.E. - Anemia and intestinal parasitic infections in primary school students in Aracaju, Sergipe, Brazil. Cadern. Saúde públ.(Rio de J.), 15: 413-421, 1999.

29. VALLADA, E.P. - Manual de exames de fezes: coprologia e parasitologia. Rio de Janeiro, Atheneu, 1988. p. 115-118.

30. WELSH, J. \& Mc CLELLAND, M. - Fingerprinting genomes using PCR with arbitrary primers. Nucleic Acids Res., 18: 7213-7218, 1990.

31. WILLIAMS, J.G.; KUBELIK, A.R.; LIVAK, K.J.; RAFALSKI, J.A. \& TINGEY, S.V. - DNA polymorphisms amplified by arbitrary primers are useful as genetic markers. Nucleic Acids Res., 18: 6531-6535, 1990.

Received: 19 March 2008

Accepted: 23 December 2008 